\title{
„JAROMĚŘICKÉ“ MONOGRAFIE VLADIMÍRA HELFERTA JAKO VZOR PRO VÝZKUM OPERY VE STŘEDNÍ EVROPĚ V PRVNÍ POLOVINĚ 18. STOLETÍ
}

V roce 2014 jsme si vedle řady jubileí velkých národních skladatelů připomněli i jedno drobnější, přesto však pro českou muzikologii důležité výročí. Uběhlo totiž celkem 90 let od vydání druhého ze zásadních děl Vladimíra Helferta věnovaných hudební kultuře v Jaroměřicích nad Rokytnou. V této souvislosti je namístě připomenout význam obou publikací, které dopředu předurčily jeden z hlavních badatelských směrů především brněnské katedry muzikologie a dodnes jsou výrazným inspiračním a částečně i metodologickým vzorem.

V rámci svého vědeckého působení se Vladimír Helfert výrazně zabýval třemi základními okruhy výzkumu, tedy obdobím vrcholného baroka v českých zemích, druhou tematickou sférou byla etapa bezprostředně následující, a to klasicismus ve spojitosti s tzv. českou hudební emigrací, zejména s postavou Jiř́ho Antonína Bendy, a konečně česká hudba 19. a 20. století. ${ }^{1}$ První projevy Helfertovy aktivní muzikologické činnosti spadají do roku 1908. Tehdy započala autorova spolupráce s řadou hudebních a uměleckých periodik jako Dalibor, Hudební sborník nebo Česká kultura. ${ }^{2}$

Signifikantní je především zájem Vladimíra Helferta o hudební kulturu pěstovanou v zámeckých lokalitách, jehož počátky můžeme hledat již v Helfertově dětství. Jeho otec, baron Zdeněk Helfert, zastával funkce ředitele velkostatku v Plánici a inspektora Bechyňského panství. Do tohoto jihočeského města se rodina záhy přestěhovala. ${ }^{3}$ Historické město Bechyně s majestátním rožmberským zámkem muselo na mladého Vladimíra velmi silně působit a snad i vyvolat onu

1 STRAKOVÁ, Theodora. Vladimír Helfert a zámecká hudební kultura. In PEČMAN, Rudolf (ed.). Vladimír Helfert $v$ českém a evropském kontextu. Svaz čes. skladatelů a koncertních umělců, Brno, 1987, s. 49. českých hudebníků z povolání, č. 30, Praha, 1940, s. 4.

3 STRAKOVÁ, Theodora. Průvodce výstavou Vladimír Helfert a jeho tvưrči odkaz. Brno, 1956, s. 15. 
budoucí snahu popsat, jaká kultura byla na podobných sídlech v minulosti pěstována. Jisté je, že se fenoménu tzv. zámecké hudební kultury počátku 18 . století - dnes bychom raději ř rekli šlechtické hudební kultury ${ }^{4}$ - začal věnovat nejpozději po získání doktorátu a nástupu do role středoškolského profesora Českoslovanské obchodní akademie v Praze. ${ }^{5}$ Mladý vědec se $\mathrm{v}$ tomto př́padě vydal vstř́íc badatelsky naprosto neprobádané oblasti, nebot' pobělohorská doba byla tehdy vnímána jako období vítězné protireformace, útlaku a nadvlády cizích uměleckých stylů.

Popud k obrácení Helfertova zájmu k moravskému městečku Jaroměřice nad Rokytnou a tamní zámecké hudební kultuře není nikde př́mo popsán. Rudolf Pečman a Theodora Straková považují za pravděpodobnou prvotní autorovu inspiraci dílo Christiana D'Elverta Geschichte der Musik im Mähren und Österreich-Schlesien. ${ }^{6}$ D'Elvert v publikaci poukazuje na dřívějš́ího vlastníka Jaroměřic, hraběte Johanna Adama z Questenbergu, coby na znalce umění a skvělého loutnistu. Dále mluví o Questenbergově dceři Karolíně, talentované cembalistce, a především o skutečnosti, že hrabě nechal na svém zámku provozovat vlastními hudebníky celé opery. ${ }^{7}$

Obě stěžejní monografie, jmenovitě Hudební barok na českých zámcích ${ }^{8}$ a druhá část Hudba na zámku v Jaroměricićch byly dokončeny již roku $1913 .{ }^{10}$ První část, publikovanou roku 1916 lze bezesporu označit jako přelomovou, jak z hlediska obsahu, tak i pojmoslovného a metodologického aspektu. Předně můžeme zdůraznit Helfertovo použití pojmu „barok“ nejen v názvu monografie, ale i v textu samotném. Tento termín Helfert rozebírá v rozsáhlé předmluvě a vymezuje jej jako kulturní zjev sloučenýs katolickou protireformací a absolutistickým monarchismem. ${ }^{11}$ Pojem pak rozebírá z hlediska náboženského, historického a výtvarného. Pro Helferta je tedy označení „barok, baroko“ synonymem protireformačních uměleckých projevů.

$4 \quad$ K problematice pojmů zámecké hudební kultury a šlechtické hudební kultury blíže KAPSA, Václav. Hudebnici hraběte Morzina: př́spěvek k dějinám šlechtických kapel v Čechách $v$ době baroka: s tematickými katalogy instrumentální tvorby Antonína Reichenauera, Christiana Gottlieba Postela a Františka Jiránka. Etnologický ústav Akademie věd České republiky, Kabinet hudební historie, Praha, 2010, s. 11-14.

5 ŠŤĚDROŇ, Bohumír. Dr. Vladimír Helfert: přehled práce českého učence. Praha, 1940, s. 4.

6 D'ELVERT, Christian. Geschichte der Musik im Mähren und Österreich-Schlesien. Brünn, 1874, s. 181.

7 D'ELVERT, Christian. Geschichte des Theaters in Mähren und Österreichisch Schlesien. Brünn 1852, s. 163.

8 HELFERT, Vladimír. Hudebni barok na českých zámcích. Jaroměřice za hraběte Jana Adama z Questenberku (†1752). Česká akademie císaře Františka Josefa pro vědy, slovesnost a umění, Praha, 1916.

9 HELFERT, Vladimír. Hudba na zámku v Jaroměřicich. František Václav Míča (1694-1744). Rozpravy České akademie věd a umění, č. 69, Praha, 1924.

10 Tamtéž, s. IV.

11 HELFERT, Vladimír. Hudební barok na českých zámcích. Praha, 1916, s. 11-24. 
V Hudebním baroku je předmětem Helfertova zájmu hudební život na jaroměřickém zámku, na jehož pozadí jako by bylo realizováno studium obecné problematiky šlechtické hudební kultury. Jaroměřice jako celek však vzhledem $\mathrm{k}$ bohatství pramenné základny nejsou srovnávány s dalšími zámeckými centry. Tento fakt Helfert považoval za nedostatek svého úsilí. ${ }^{12}$ Jako jediná možná metoda výzkumu se $\mathrm{v}$ tomto prípadě jevila detailní práce $\mathrm{s}$ dochovanými prameny, zhodnocení získaných informací, jejich interpretace a konečně srovnání s hudbou zahraniční provenience. Helfert zdůrazňuje, že ve své práci nemá předchůdců a neměl tudíž ani na co navázat. ${ }^{13} \mathrm{Za}$ nejdůležitější považuje autor listinné prameny z hraběcího rodinného archivu, tehdy deponovaného př́mo v Jaroměřicích, a dochované dílo Františka Míči, tedy partitury a tištěná libreta.

Metoda důsledné heuristiky byla v české hudební historiografii použita vůbec poprvé. Na téměř 400 stranách se Helfertovi podařilo kompletně zmapovat historii jaroměřického panství v období vlastnictví Questenbergů, přičemž samozřejmě středem zájmu je poslední a také nejvýznamnější potomek rodu, hrabě Johann Adam. Další části popisují jaroměřickou zámeckou kapelu a její hlavní osobnosti, jaroměřickou hudební kulturu ve vztahu s ostatními vybranými hudebními centry, přičemž klíčový pro Helfertovo srovnávání je logicky hudební život u vídeňského císařského dvora v čele s tvorbou Antonia Caldary, Johanna Josepha Fuxe, Francesca Bartolomea Contiho a dalších. V této kapitole také popisuje př́mé či zprostředkované styky hraběte se skladateli, a dále s evropskými operními centry, včetně Prahy a Brna. Konečně poslední část líčí vlastní hudební život na jaroměřickém zámku. Z názvů jednotlivých kapitol je patrné, že každá by mohla tvořit samostatnou monografii. Publikace tak výrazně překračuje svůj rámec. Jedinou menší „vadou” Hudebního baroku je značná podrobnost některých pasáží pramenící z Helfertových obecně historických a literárně historických sond (nutno ovšem podotknout, že podobnému problému čelí i dnes řada z nás, zejména pokud se jako Helfert ocitáme před dosud nezpracovanými tématy a prameny).

V př́ípadě výrazného pozdržení vydání druhé částí díla lze paradoxně mluvit o pozitivním dopadu, nebot' Helfert v této době objevil soubor operních a oratorních tištěných libret jaroměřické provenience na zámku Nové Hrady. Mohl tak své dílo výrazně doplnit. ${ }^{14}$ Hudba na Jaroměřickém zámku vyšla tiskem až roku 1924 nákladem České akademie věd a umění. O čtyři roky dř́ve, 15. zář́í 1920, předložil její autor spis jako habilitační na nově vzniklé Masarykově universitě. Dochovaná zpráva habilitační komise, jíž předsedal Otakar Zich, vyzdvihuje především př́nos dosavadních Helfertových textů o Jiřím Bendovi a dále prvního dílu jaroměřických monografií. Stran obsahu pak kladně hodnotí Helfertovy

12 Tamtéž, s. II.

13 Tamtéž.

14 STRAKOVÁ, Theodora. Vladimír Helfert a zámecká hudební kultura. In PEČMAN, Rudolf (ed.) Vladimír Helfert v českém a evropském kontextu. Svaz čes. skladatelů a koncertních umělců, Brno, 1987, s. 50. 
závěry o společných prvcích v tvorbě Františka Míči a symfoniích tzv. mannheimské školy. Komise vytýká pouze některé ukvapené závěry, např. že česká lidová píseň je „eklektická a italská“, a to na základě výčtu shod mezi lidovými písněmi a tvorbou Františka Míči. ${ }^{15}$

Neopomenutelným zdrojem informací o autorových záměrech a poslání díla je i v tomto př́padě předmluva. Na rozdíl od Hudebního baroku zde Helfert nemluví o potenciálním nedostatku (srovnání více zámeckých kultur). Byl patrně se svou prací, snad díky možnosti pozdější aktualizace, zcela spokojen. Téměř úsměvně pak působí autorova omluva značného rozsahu práce: účelem bylo dát obdobným studiím spolehlivý základ, o nějž by bylo možno se opřit, ${ }^{16}$ nebot' ani zde neměl autor žádné předchůdce. Touto poznámkou jsou vyjádřeny dvě důležité myšlenky. Před Helfertem opět stálo pole naprosto neorané, tedy bylo třeba znovu kompletně zmapovat problematiku a zvolit funkční metodu - onen spolehlivý základ. Zároveň i zohledňuje možnost, že se v budoucnu najdou badatelé, kteř́ budou $\mathrm{v}$ jeho díle pokračovat.

Po důkladném kritickém zhodnocení pramenů a popsání jaroměřického hudebního života bylo nutné obrátit pozornost $\mathrm{k}$ dochovaným dílům - jak v podobě partitur, tak tištěných libret, coby př́mým dokladům o umění dané doby. Jejich analýzou je možné získat odpovědi na otázky o společenské funkci děl a poté vyvodit charakteristiku prostředí, v němž vznikla. Obsahem první kapitoly Hudby na zámku v Jaroměricích je podrobná analýza dochovaných textů k Míčovým dílům. Helfert zde plně zúročil své hluboké znalosti literárně-historické. Např. texty jaroměřických sepolker srovnává, pokud je to možné, s texty stejného žánru, nejčastěji vídeňské provenience. Rovněž se věnuje pozoruhodnému jaroměřickému fenoménu, a to českým textům, popř. překladům. Tuto problematiku blíže hodnotí v Hudebním baroku, kde překvapivě a ne zcela oprávněně zaujímá $\mathrm{k}$ danému specifiku poněkud rezervované stanovisko. Provozování operních a oratorních děl $\mathrm{z}$ příkazu hraběte $\mathrm{v}$ češtině není možné spojovat $\mathrm{v}$ tomto období $\mathrm{s}$ národnostním hlediskem. Jazyk je tu podle Helferta pouze sdělovacím prostředkem. ${ }^{17}$ Měl-li být naplněn obsah Questenbergovy universitní teze o zušlecht'ování poddaných hudbou, $\mathrm{v}$ tomto príípadě zejména dramatickou, museli poddaní textu provozovaných děl rozumět. Překladatelem textů byl jaroměřický děkan Antonín Ferdinand Dubravius. Ten neměl ve sledované době potřebný vzorový materiál, nebot' provozování děl v češtině bylo téměř unikátní. Helfert se proto obrátil k jezuitským školským hrám. Srovnávacím materiálem mu byly především hry s českým textem od Josefa Hubatky. V porovnání s Hubatkovými verši jeví se Helfertovi Dubraviova práce jako logicky zřetelná, jeho verše jsou po formální stránce jasné. $\mathrm{Z}$ dochovaných textů nejvýše hodnotí Dubraviův překlad

15 ZICH, Otakar - NAVRÁTIL, Bohuslav - HAŠKOVEC, Prokop. Zpráva komise pro habilitaci Vladimíra Helferta. In PEČMAN, Rudolf. Vladimir Helfert. Nadace Universitas Masarykiana, Brno, 2003, s. 185-187.

16 HELFERT, Vladimír. Hudba na zámku v Jaroměřicích. Praha, 1924, s. III.

17 HELFERT, Vladimír. Hudebni barok na českých zámcích. Praha, 1916, s. 88. 
stěžejního Míčova díla - opery L'Origine di Jaromeritz in Moravia s původním textem Domenica Bonliniho, nebot' zde musel, na rozdíl od sepolker, kde měla česká verze pouze informativní charakter, uzpůsobit překlad zpěvu. ${ }^{18}$

Po textové stránce se Helfertova pozornost upřela k Míčovu zhudebnění. Jak Helfert zdůrazňuje $\mathrm{v}$ předmluvě, neexistovala žádná metoda, kterou by mohl v př́padě analyzování děl z počátku 18. století aplikovat. Stanovil proto metodu novou, jež měla být vzorovou pro budoucí práce. Metoda vycházela z tzv. melodického alfabetu a čerpala z díla Helfertova učitele Otakara Hostinského Třicet šest nápěvů světských písni českého lidu z 16. stoleti ${ }^{19}$ a o čtrnáct let mladší Česká světská píseň lidová. ${ }^{20}$ Předmětem Hostinského výzkumu byl vztah mezi kancionálovými písněmi a nápěvy lidových písní. Metoda melodického alfabetu spočívala $\mathrm{v}$ tomto případě ve vytvoření šesti melodických typů, jež měly postihnout celou Míčovu tvorbu. Za základní byla takto považována právě melodická stránka Míčovy hudby, zatímco její rytmická složka, nehledě na ostatní faktory pro barokní hudbu typické, zohledněny nebyly. Tato metoda tak má v rámci analytického zkoumání barokní hudby, zejména pak vokálně instrumentální, své výrazné limity. Její aplikace, stejně jako Helfertův obdiv k Bedřichu Smetanovi, který dle něj teprve vyvedl naše hudebníky z pout omezenosti, a řada dalších faktorů, vedly Helferta $\mathrm{k}$ formulaci př́liš př́krých závěrů, především o primitivismu $v$ Míčově tvorbě, s nimiž dnes nemůžeme zcela souhlasit. ${ }^{21}$ Podobně sporné jsou i Helfertovy soudy, které přináší další kapitoly věnované slohu Míčových děl, a to zejména o předjímání hudebního klasicismu v Míčově díle, hledání kořenů mannheimské školy v české a moravské dobové hudební produkci nebo již zmíněné ovlivnění české lidové písně umělou barokní italskou hudbou. Tyto závěry však byly historicky determinovány a není tudíž na místě je jen slepě kritizovat a vytýkat.

Byla to právě opera, povětšinou italská, která se stala nerozlučnou složkou barokní kultury, i největší vášní hraběte Questenberga, a tedy hlavním sledovaným žánrem Helfertových monografí́. Mluvíme-li o barokní opeře, je vedle historického bádání a analýzy důležitou součástí výzkumu také rozbor dochovaných tištěných libret, a to zejména u těch děl, $\mathrm{k}$ nimž není dochována hudba. I v př́ípadě libretistiky přináší Helfert podrobný vzor, a to v rámci studie Opera o Donu Juanu v Brně roku $1734 .{ }^{22}$ Helfert se v rámci něj zaměřil na tištěné libreto k opernímu pasticciu La Pravità castigata. V rámci svého výzkumu neopomenul zohlednit další složky barokní opery, o nichž tištěné libreto, na rozdíl od většiny partitur, podává podrobné svědectví. Helfert pochopil, že tištěné libreto není

18 HELFERT, Vladimír. Hudba na zámku v Jaroměřicích. Praha, 1924, s. 31-40.

19 HOSTINSKÝ, Otakar. Třicet šest nápěvư světských písní českého lidu z 16. století. F. Šimáček, Praha, 1892.

20 HOSTINSKÝ, Otakar. Česká světská píseñ lidová: úvahy národopisné a hudební. F. Šimáček, Knihovna Českého lidu, sv. 4, Praha, 1906.

21 PERUTKOVÁ, Jana. František Antonín Míča ve službách hraběte Questenberga a italská opera v Jaroměricich. Koniasch Latin Press, Praha, 2011, s. 216-217.

22 HELFERT, Vladimír. Opera o Donu Juanu v Brně r. 1734. In Časopis Matice moravské 41-42, Brno, 1917-1918, s. 249-265; 43-44, 1919-1620, s. 65-108. 
pouze dokladem o provedení opery, ale také cenným pramenem k poznání operní společnosti, vybavení divadla, dramaturgii, apod.

Již byl zdůrazněn př́nos Helfertových jaroměřických monografií z hlediska zpracování tématu do té doby naprosto opomíjeného, stejně jako metodologického zdroje, byt' nyní částečně překonaného. Nutné je ovšem poukázat na ještě jeden důležitý význam Helfertova díla, a to inspirativnost pro budoucí generace hudebních historiků, zejména při výzkumu barokní opery a oratoria ve střední Evropě. Ovlivnění Helfertovou prací, k níž v tomto ohledu musíme připočíst kromě uvedené libretistické studie také nedokončenou monografii o Jiř́m Antonínu Bendovi, ${ }^{23}$ je v následujícím výzkumu barokní hudby, respektive opery, patrné ve dvou rovinách. Někteří badatelé př́mo navazují na Helfertův výzkum jaroměřické lokality a přináší nové poznatky či aktualizují dosavadní závěry. Pro další je Helfertovo dílo oním základem, o nějž je možné se opřit - jak po stránce metodologické, tak i formální, přičemž v této oblasti se nutně dostáváme i mimo operní prostředí.

Již v době Helfertova života začali se ubírat ve stopách svého učitele napřr. Bohumír Štědroň, který stejně jako Helfert podnikl studijní cestu do Itálie, na základě níž roku 1933 obhájil svoji disertaci Sólové chrámové kantáty Giovanni Batisty Bassaniho. Př́spěvek k poznáni hudebního stylu známého v Brně ca. $1700{ }^{24}$ Dále to byli zejména manželé Vincenc a Theodora Strakovi. Vincenc Straka ve své disertaci Život a dílo P. Simona a S. Barholomaeo. Př́spěvek $k$ dějinám chrámové hudby $v$ 18. století. zcela a v podstatě beze změny přejímá Helfertův model, který se již zřetelně ukazuje jako nefunkční. ${ }^{25}$ Theodora Straková, jejíž dílo o hudbě 18. a částečně 17 . století není třeba dlouze představovat, pokračovala ve studiu jaroměřické problematiky. Výsledky své práce publikovala v několika studiích. ${ }^{26}$ Inspirována dílem svého učitele se rovněž pokusila popsat hudební kulturu na dvoře hrabat z Collalta a San Salvatoru. ${ }^{27}$ K výčtu Helfertových žáků

23 HELFERT, Vladimír. Jiři Benda: přispěvek k problému české hudebni emigrace. I. část, (Základy). Filosofická fakulta s podporou Ministerstva školství a národní osvěty, Brno, 1929; HELFERT, Vladimír. Jiři Benda: Přispěvek k problému české hudebni emigrace. II. části, 1. dil, (Gotha 1750-1774). Filosofická fakulta, Brno, 1934.

24 ŠŤĚDROŇ, Bohumír. Dr. Vladimír Helfert: přehled práce českého učence. Praha, 1940, s. 24.

25 STRAKA, Vincenc. Život a dílo P. Simona a S. Barholomaeo. Přispěvek k dějinám chrámové hudby v 18. století. Filosofická fakulta, Brno, 1946.

26 STRAKOVÁ, Theodora. Jaroměrice nad Rokytnou. In Opus Musicum 4, 1973, č. 2, s. 57 60; STRAKOVÁ, Theodora. Jaroměřice nad Rokytnou a jejich význam v hudebním vývoji Moravy. In PLICHTA, Alois (ed.). O životě a uméní. Listy z jaroměřické kroniky 1700-1752. Jaroměřice nad Rokytnou 1974, s. 393-404; STRAKOVÁ, Theodora. Hudba na moravských zámcích. In Studie Muzea Kroměř́žska 1991. [= Vlastivědná knihovna moravská, 80], Kroměříž - Brno 1992, s. 18-21; STRAKOVÁ, Theodora. Die Questenbergische Musikkapelle und ihre Repertoire. In Sbornik praci Filozofické fakulty brněnské univerzity, H 31, 1996 [Brno 1997], s. 13-23.

27 STRAKOVÁ, Theodora. Hudebníci na collaltovském panství v 18. století. In Časopis Moravského Musea 51, Brno, 1966, s. 231-268. 
kráčejících v jeho stopách je nutné připojit ještě Jana Racka, i když v oblasti jaroměřického bádání byl jeho vklad nanejvýš problematický. Známá je zejména Rackova předmluva k edici Sinfonie in Re, kterou Racek připsal jaroměřickému kapelníkovi, což si vysloužilo několik let trvající polemiku a následné vyvrácení tohoto tvrzení.

Helfertův odkaz byl a stále je rozvíjen následujícími generacemi muzikologů i historiků. Na tomto místě je nutné zdůraznit př́nos Jiř́ího Sehnala a jeho obsáhlé dílo věnované hudbě 17 . a 18 století. Zmiňme např́íklad publikace o kapele a hudebním životě na dvoře olomouckého biskupa Karla Liechtensteina-Castelcorno. Zcela zásadní je Sehnalova studie Počátky opery na Moravę ${ }^{28}$ zaměřená na výzkum moravských operních center kromě Jaroměřic, v rámci níž je Morava první poloviny 18 . století vykreslena jako lokalita s intenzivním operním provozem. Helfertova studie Opera o Dопи Jиапи v Brně 1734 byla cenným zdrojem poznatků pro Tomislava Volka, který v tomto směru navázal na Helferta několika pracemi, $v$ nichž nejenže zhodnotil význam jeho textů, ale dále doplnil jeho výzkum o poznatky k pražskému uvedení pasticcia La Pravità castigata. ${ }^{29}$ Díky svým seminářům o hudbě 17 . a 18 . století na pražské katedře hudební vědy mimo jiné přivedl k zájmu o barokní hudbu několik badatelů, kteří se tímto obdobím intenzivně zabývají. Za všechny jmenujme Miladu Jonášovou, Janu Spáčilovou, Václava Kapsu, Tomáše Slavického a Ondřeje Macka.

Přínos Vladimíra Helferta a jeho díla ve svých pracích neutuchajícím způsobem zdůrazňoval Rudolf Pečman, zejména v monografii Vladimír Helfert, ${ }^{30} \mathrm{v}$ jím editovaném konferenčním sborníku Vladimír Helfert v českém a evropském kontextu, ${ }^{31}$ či statí Preambulum aneb Brněnská muzikologie v době počátku a prvnich vzmachü. ${ }^{32}$ Podobné cíle sledujeme i ve studiích Jiřího Vysloužila, Jiř́ího Fukače a mnoha dalších.

28 SEHNAL, Jiř́i. Počátky opery na Moravě. In O divadle na Moravě. Acta Universitatis Palackianae Olomucensis, Facultas Philisophica Supplementum 21, Praha, 1974, s. 55-77.

V tomto ohledu je kromě nepublikované studie Prvni pražská opera o Donu Giovannim nutné zmínit VOLEK, Tomislav. Pražská operní tradice a Mozartův Don Giovanni. In Mozartův Don Giovanni: katalog k výstavě ke 200. výroči světové premiéry v Praze 1787-1987. Praha 1987, s. 21-91, v níž se k předchozí práci odkazuje a dále VOLEK, Tomislav. 90 Jahre seit dem Erscheinen der Studie von Vladimir Helfert über Don-Juan-Oper in Brünn 1734. In MACEK, Petr - PERUTKOVÁ, Jana (ed.). The Eighteenth - Century Italian Opera Seria: Metamorphoses of the Opera in the Imperial Age, International Musicological Colloquium., Colloquia Musicologica Brunensia, 42, Koniasch Latin Press, Praha, 2013, s. 115-125. Význam díla Vladimíra Helferta cenným způsobem zhodnotil tento autor v práci VOLEK, Tomislav. Helfert stále aktuální. In Opus Musicum, č. 10, 1986, s. 306-310.

PEČMAN, Rudolf. Vladimír Helfert. Nadace Universitas Masarykiana, Brno, 2003.

31 PEČMAN, Rudolf (ed.). Vladimír Helfert v českém a evropském kontextu. Svaz čes. skladatelů a koncertních umělců, Brno, 1987.

32 PEČMAN, Rudolf. Preambulum aneb Brněnská muzikologie $\mathrm{v}$ době počátku a prvních vzmachů. In Musicologia Brunensis. Ad honorem Jan Racek, Bohumír Štédroň et Zdeněk Blažek 1905-2005. Koniasch Latin Press, Praha, 2005, s. 7-32. 
V bádání o Jaroměřicích našlo Helfertovo dílo pokračovatele v právníku Aloisi Plichtovi (1905-1993). Plichta díky výzkumu dalších relevantních jaroměřických archiválií doplnil Helfertovy závěry o řadu nových poznatků. Chyběly mu však znalosti pro daný výzkum podstatných vědních disciplín, především muzikologie a kunsthistorie. Svými pracemi tak bohužel přispěl i ke vzniku řady omylů a mýtů. ${ }^{33}$ Obecně historickému výzkumu Jaroměřic za Jana Adama z Questenbergu se dále v letech 2000-2005 věnoval Rostislav Smíšek z Jihočeské univerzity. ${ }^{34}$

Současný muzikologický výzkum Jaroměřic je i nadále primárně spjat $\mathrm{s}$ brněnskou katedrou muzikologie, a to především díky Janě Perutkové, která se této tematice dlouhodobě intenzivně věnuje. Již ve své diplomové práci v r. 1993 navázala na Helferta, když se zaměřila na Míčovu gratulační serenatu Der glorreiche Nahmen Adami, jejíž partitura nebyla Helfertovi známa. Vedle Jany Perutkové se výzkumu gratulačních serenat, tentokrát však spjatých s císařským dvorem, věnovala také Irena Veselá. Ta ve své diplomové práci Gratulačni opera La Concordia de' Pianeti a její provedení ve Znojmě roku 1723 rovněž navázala na Helfertův vzor a zaměřila se nejen na historické okolnosti uvedení serenaty Antonia Caldary ve Znojmě, ale rovněž i na analýzu díla ${ }^{35}$ Podobně postupovala při tvorbě disertační práce, $\mathrm{v}$ rámci níž se věnovala gratulačním kompozicím uvedeným v době pobytu císaře Karla VI. a jeho manželky, císařovny Alžběty Kristýny, v Praze roku $1723 .{ }^{36}$

Za důležitou etapu v bádání o opeře na Moravě v první polovině 18 . století můžeme považovat období od roku 2005 , kdy byly realizovány rozsáhlé výzkumné projekty Italská opera na Moravě v první polovině 18. století a Výzkum operního repertoáru $v$ českých zemích doby baroka. Klíčovým prínosem tohoto projektu bylo především objevení množství operních a oratorních partitur z původního majetku hraběte Questenberga, nyní uložených především v Österreichische Nationalbibliothek a archivu Gesellschaft der Musikfreunde. Hudebniny ze sbírky hraběte Questenberga byly do té doby obecně považovány za nedochované

33 PLICHTA, Alois (ed.). O životě a umění. Listy z jaroměřické kroniky 1700-1752, Jaroměřice nad Rokytnou, 1974; PLICHTA, Alois. Hudba a hudebníci v Jaroměřicích nad Rokytnou po smrti J. Adama z Questenberka (1752-1790). In Hudebni věda, č. 2, 1986, s. 166-174; PLICHTA, Alois. Jaroměřicko. Dějiny Jaroměric nad Rokytnou a okolí. I-II, Třebíč, 1994.

34 SMÍŠEK, Rostislav. Rezidence a dvưr hraběte Jana Adama Questenberka v Jaroměricích nad Rokytnou v první polovině 18. století. Diplomová práce, Jihočeská univerzita, České Budějovice, 2000; SMÍŠEK, Rostislav. Jan Adam Questenberk mezi Vídní a Jaroměricemi. In BÜŽEK, Václav - KRÁL, Pavel (ed.). Šlechta v habsburské monarchii a císařský dvůr (1526-1740). Opera historica, sv. 10, České Budějovice, 2003, s. 331-354; SMÍŠEK, Rostislav. Jan Adam z Questenberka a hmotná kultura v zámku v Jaroměřicích nad Rokytnou. Př́ispěvek ke šlechtické reprezentaci v první polovině 18. století. In Západni Morava. Muzejní a vlastivědná společnost v Brně, roč. 9, Brno, 2005, s. 50-70.

35 VESELÁ, Irena: Gratulační opera La Concordia de' Pianeti a její provedení ve Znojmě roku 1723. Diplomová práce, FF MU, Brno, 2001.

36 VESELÁ, Irena: Císařský styl v hudebně-dramatických dílech provedených za pobytu císaře Karla VI. v českých zemích roku 1723. Disertační práce, FF MU, Brno, 2007. 
i přes to, že Vladimír Helfert ve svém díle naznačil možnost jejich existence. ${ }^{37}$ V rámci výzkumu bylo identifikováno přes 40 partitur. Po této pro dějiny hudby na Moravě zásadní události vyvstala nutnost vedle hudebnin a tištěných libret znovu prozkoumat jaroměřické archiválie a aktualizovat Helfertovy poznatky. Bylo tak učiněno v mnoha dílčích studiích badatelského týmu (Jana Perutková, Jana Spáčilová, Ondřej Macek a Vladimír Maňas) a posléze v monografii Jany Perutkové s názvem František Antonín Míča ve službách hraběte Questeneberga a italská opera v Jaroměřicich. Ta podává aktualizovaný přehled informací $\mathrm{k}$ problematice, včetně nových poznatků k rozvětvenému rodu Míčů.

Zásadní částí monografie je především analýza dochovaných děl Františka Antonína Míči, realizovaná s ohledem na nejnovější poznatky o skladebných principech hudby 18 . století. Nová metoda analýzy klade důraz na těsný vztah hudby a slova spojený s afektovou teorií a hudební symbolikou, dále na melodický duktus, rytmickou složku, vztah jednotlivých hlasů a deklamaci při zhudebňování textu. ${ }^{38}$ Jana Perutková, stejně jako před několika desítkami let Vladimír Helfert, předložila svoji monografii jako habilitační spis. Německá knižní publikace, kterou v současné době autorka pod názvem Johann Adam Graf Questenberg (1678-1752) als Förderer der italienischen Oper in Mähren připravuje, stejně jako již publikované německé studie $\mathrm{k}$ dílčí problematice, pomohou napravit fakt, který lze pocitovat jako určitou „slabinu“ Helfertových prací, a tím je jejich jazyková nesrozumitelnost pro většinu zahraničních badatelů. ${ }^{39}$ Ti tak budou moci lépe uchopit problematiku hudebního života $\mathrm{v}$ Jaroměřicích $\mathrm{v}$ Questenbergově době, nebot' ta není pouze významnou součástí českého hudebního dědictví, ale měla velký význam i v kontextu dějin hudby ve střední Evropě.

Výzkum barokní opery na Moravě od roku 2005 pokračuje až do současnosti. V r. 2006 obhájila svoji disertaci Hudba na dvoře olomouckého biskupa Schrattenbach $a^{40}$ Jana Spáčilová, která se v rámci tématu rovněž vydala v Helfertových

PERUTKOVÁ, Jana. František Antonín Míča ve službách hraběte Questenberga a italská opera v Jaroméřicich. Praha, 2011, s. 10.

Tamtéž, s. 216-217.

39 PERUTKOVÁ, Jana. Zur Identifizierung der Questenbergischen Partituren in Wiener Musikarchiven. In Hudební věda, č. 1, 2007, s. 5-34; PERUTKOVÁ, Jana. Johann Adam Mitscha (1746-1811). Ein Wiener Zeitgenosse Mozarts. In Studien zur Musikwissenschaft. Hans Schneider, Tutzing, 2007, s. 61-72; PERUTKOVÁ, Jana. Giulio Cesare in Egitto am Wiener Kärntnertortheater im Jahre 1731. Ein Beitrag zur Rezeption der Werke von G. F. Händel in der Habsburgermonarchie in der 1. Hälfte des 18. Jahrhunderts. In Hudebni véda, roč. 49, č. 1-2, Praha, 2012, s. 95-122; PERUTKOVÁ, Jana. Neu identifizierte Opernpartituren aus der Musiksammlung des Grafen Johann Adam von Questenberg. In MACEK, Petr - PERUTKOVÁ, Jana (ed.). The Eighteenth - Century Italian Opera Seria: Metamorphoses of the Opera in the Imperial Age, International Musicological Colloquium. Praha, 2013, s. 55-70; PERUTKOVÁ, Jana. Die von Questenbergschen Musikern aufgeführten Oratorien in Mähren in der 1. Hälfte des 18. Jahrhunderts. In Musicologica Brunensia. Masarykova univerzita, roč. 49, č. 1, 2014, s. 163-174.

40 SPÁČILOVÁ, Jana. Hudba na dvoře olomouckého biskupa Schrattenbacha (1711-1738). Př́ispěvek k libretistice barokni opery a oratoria. Disertační práce, FF MU, Brno, 2006. 
stopách, a to hned ve dvou směrech. Předně se této problematice chtěl Helfert sám věnovat, což naznačuje v bodě 11 ve svých literárních plánech sepsaných 11 . ledna $1942 \mathrm{v}$ nemocnici ve Wohlau. ${ }^{41}$ Vzhledem $\mathrm{k}$ tomu, že svědectvím o hudbě na dvoře biskupa jsou z naprosté většiny tištěná libreta, navázala Jana Spáčilová rovněž na Helfertovy poznatky z oblasti libretistiky, na základě níž podala vyčerpávající obraz o operním a oratorním provozu v moravských rezidencích kardinála Schrattenbacha. Výzkum rozšířila na některé aspekty hudebního života na holešovském zámku za hraběte Rottala a na brněnskou městskou operní scénu. V současné době připravuje do tisku rozsáhlý soupis tištěných libret pod názvem: Catalogue of the Italian Opera Libretti in Central Europe in the 1st Half of the 18th Century, respektive jeho první část evidující libreta dochovaná na Moravě.

Obecně historická a muzikolgická hlediska v rámci svého výzkumu propojil člen již zmiňovaného badatelského týmu - Vladimír Maňas. Ve svých studiích se věnoval barokním slavnostem v Jaroměřicích a Holešově roku $1739,{ }^{42}$ dále pohřbu jaroměřického děkana Josefa Joachima rytíře ze Stehna ${ }^{43}$ či již zmiňovanému překladateli některých „questenberských“ libret Antonínu Ferdinandovi Dubraviovi. ${ }^{44}$

Naplněny byly rovněž Helfertovy požadavky na uvádění výsledků výzkumu do praxe. V rámci uvedených projektů objevil Ondřej Macek části Vivaldiho opery Argippo. Operu v Mackově rekonstrukci provedl roku 2008 soubor Hof-Musici. Soubor také nastudoval několik děl spjatých s Jaroměřicemi, jejichž partitury uložené ve Vídni se podařilo identifikovat jako „questenberské“ - jmenujme např. Hasseho serenatu La Semele nebo Porsileho oratorium Il Sacrificio di Gefte. Řada z uvedených badatelských výsledků byla prezentována na muzikologických, historických i teatrologických konferencích u nás i v zahraničí, především pak v Rakousku a Německu.

Návaznost na Helfertovo dílo a zájem o hudební život v Jaroměřicích nalézáme i v diplomových pracích současných studentů muzikologie. Vedle mé diplomové práce Opera Amalasunta a její vztah k jaroméřickému opernímu provozu ${ }^{45}$ zmiňme např́klad bakalářskou práci Blanky Kašpárkové Zpěváci a hudebníci na dvoře hraběte J. A. Questenberga i magisterskou práci stejné autorky Rok $1736 v$ životě hraběte Johanna Adama Questenberga - pramenné sondy, ${ }^{46}$ a řady

41 PEČMAN, Rudolf. Vladimír Helfert. Nadace Universitas Masarykiana, Brno, 2003, s. 179180

42 MAŇAS, Vladimír. Slavnosti v Jaroměřicích a Holešově roku 1739 ve světle šlechtické korespondence. In Opus Musicum, č. 3, Brno, 2011, s. 6-12.

43 MAŇAS, Vladimír. Jaroměřický děkan Josef Joachim rytí̌ ze Stehna a jeho pohřeb v roce 1778. Př́spěvek k poznání lokální hudební kultury. In Opus Musicum, č. 6, Brno, 2010, s. 62-71.

44 MAŇAS, Vladimír. K osudům moravského barokního kazatele Antonína Ferdinanda Dubravia. In Opus Musicum, č. 1, Brno, 2010, s. 31-41.

45 SLOUKA, Petr. Opera Amalasunta a její vztah k jaroměřickému opernímu provozu. Diplomová práce, FF MU, Brno, 2011.

46 KAŠPÁRKOVÁ, Blanka. Zpěváci a hudebnici na dvoře hraběte J. A. Questenberga. Baka- 
dalších dnes již absolventů vedených Janou Perutkovou. Serenata Il Natale di Giove (1742) Questenbergova dosud méně známého skladatele Karla Müllera je tématem vznikající diplomové práce Michaely Macháčkové. Na Helfertovo upozornění o propojení operních center Prahy, Vratislavi a Jaroměřic navazuje Zuzana Veverková. Její budoucí disertační práce přiblíži klíčovou osobnost Antonia Bioniho coby šiřitele opery seria do zaalpského prostoru a také jednu ze spojnic mezi jmenovanými centry.

Jak se ukazuje, moravská hudbymilovná šlechta a jejich zájem o provozování opery a oratoria je do značné míry jedinečným fenoménem. Četné důkazy pro to přinášejí právě questenberské prameny, které svým bohatstvím a šǐrí př̀dstavují ojedinělý zdroj informací nejen pro Jaroměřice samotné, ale i pro další výzkumy ohledně moravské aristokracie, a to z hlediska hned několika vědních oborů. První sondu do této problematiky představuje studie Jany Perutkové Moravská hudbymilovná aristokracie v 1. polovině 18. století a její vztah ke světským hudebně dramatickým produkcimm. ${ }^{47}$ Dílčím výsledkem je i studie Jany Perutkové a Vladimíra Maňase Pašijové oratorium ve Znojmě roku 1734 - př́spěvek $k$ poznáni hudebního života na Moravě (Opus musicum, 2012). ${ }^{48}$ Zde vidíme návaznost na Helfertovy snahy o výzkum dalších moravských lokalit a o jejich srovnání. Ve světle těchto a dalších bádání se navíc stále více ukazuje nezbytnost interdisciplinárního výzkumu mezi muzikologií, obecnou historií, teatrologií a kunsthistorií (primárně na poli hudebnědramatických produkcí).

Vladimír Helfert v předmluvě k Hudebnímu baroku zdůrazňuje: Účelem této práce jest podati na konkrétním prípadě obraz hudebnich pomèrü a hudebniho života na šlechtických zámcích zemí českých $v$ době Karla VI. ${ }^{49} \mathrm{~V}$ dnešní době bychom však Helfertovy ,jaroměřické“ monografie zpětně označili za monumentální fresku, která dopředu vytyčila jedno z hlavních témat výzkumu neodmyslitelně spjatého s brněnskou katedrou muzikologie. Helfertův primát v české a světové muzikologii ohledně intenzivního zájmu o hudební baroko je nezpochybnitelný. Mnoho jeho poznatků zůstává dodnes aktuálních. Důležitá je rovněž hodnota Helfertova díla coby inspirace pro další bádání, zejména o fenoménu opery seria.

$\mathrm{V}$ době Helfertových výzkumů $\mathrm{v}$ Jaroměřicích mu často dělal společnost vrcholný představitel českého symbolistního básnictví Otokar Březina. Ten ve svém dopisu Vladimíru Helfertovi z listopadu 1916 poděkoval za darovanou knihu $\mathrm{Hu}$ debni barok na českých zámcích a dodal slova, jimiž zcela výstižně zhodnotil

lářská diplomová práce, FF MU, Brno, 2010; KAŠPÁRKOVÁ, Blanka. Rok 1736 v životě hraběte Johanna Adama Questenberga - pramenné sondy. Diplomová práce, FF MU, Brno, 2013.

PERUTKOVÁ, Jana. Moravská hudbymilovná aristokracie v 1. polovině 18. století a její vztah ke světským hudebně dramatickým produkcím. In Opus Musicum, roč. 45, č. 3, Brno, 2013, s. 6-12. spěvek k poznání hudebního života na Moravě. In Opus Musicum, roč. 44, č. 3, Brno, 2012, s. 6-13. 
Helfertovu práci: Kniha Vaše je plná života, bohatá novými postřehy, perspektivami, fakty, mladistvá a výmluvná, dílo nejen historika, ale i umělce. Postihujete mocně, jak všechny věci, i zjevy a gesta zdánlivě bez širšího dosahu a rezonance spjaty jsou v grandiózní jednotě života a ducha.

Petr Slouka (slouka@lobkowicz.cz), Lobkowiczké sbírky, zámek Nelahozeves.

\section{ABSTRACT \\ VLADIMÍR HELFERT'S MONOGRAPHS ABOUT MUSICAL CUL- TURE IN JAROMĚŘICE NAD ROKYTNOU AS A MODEL FOR RE- SEARCH OF OPERAS FROM THE FIRST HALF OF 18TH CENTURY}

Vladimír Helfert's monographs about musical culture at Jaroměřice nad Rokytnou predetermined one of the main research streams, primarily connected with the Musicology department at Masaryk University, Brno. Up to these days they are considerable inspirational and partially also methodological example; particularly in the research of the Opera Seria and Oratorio in the first half of 18 th century. $90^{\text {th }}$ year anniversary of the first edition of the second monograph pointed out a necessity of evaluation and currency of Helfert's basic scientific works again.

\section{Key words}

Vladimír Helfert, High Baroqe Period at Moravia, Baroque Opera, Johann Adam Questenberg, František Antonín Míča, Jaroměřice nad Rokytnou

\section{Bibliography}

BERKOVEC, Jiří. Podněty Vladimíra Helferta v oblasti bádání o staré opeře, zejména na scéně šporkovské a vratislavské. In PEČMAN, Rudolf (ed.). Vladimír Helfert v českém a evropském kontextu. Svaz čes. skladatelů a koncertních umělců, Brno, 1987, s. 47-49.

D'ELVERT, Christian. Geschichte des Theaters in Mähren und Österreichisch Schlesien. Brünn 1852.

D'ELVERT, Christian. Geschichte der Musik im Mähren und Österreich-Schlesien. Brünn, 1874.

HELFERT, Vladimír. Hudebni barok na českých zámcích. Jaroměrice za hraběte Jana Adama z Questenberku (†1752). Česká akademie císaře Františka Josefa pro vědy, slovesnost a umění, Praha, 1916.

HELFERT, Vladimír. Opera o Donu Juanu v Brně r. 1734. In Časopis Matice moravské 41-42, Brno, 1917-1918, s. 249-265; 43-44, 1919-1620, s. 65-108.

HELFERT, Vladimír. Hudba na zámku v Jaroměřicích. František Václav Míča (1694-1744). Rozpravy České akademie věd a umění, č. 69, Praha, 1924.

HELFERT, Vladimír. Jiři Benda: přispěvek k problému české hudebni emigrace. I. část, (Základy). Filosofická fakulta s podporou Ministerstva školství a národní osvěty, Brno, 1929.

HELFERT, Vladimír. Jiři Benda: Př́spěvek k problému české hudební emigrace. II. části, 1. díl, (Gotha 1750-1774). Filosofická fakulta, Brno, 1934.

HOSTINSKÝ, Otakar. Třicet šest nápěvů světských písni českého lidu z 16. století. F. Šimáček, Praha, 1892. 
HOSTINSKÝ, Otakar. Česká světská píseñ lidová: úvahy národopisné a hudební. F. Šimáček, Knihovna Českého lidu, sv. 4, Praha, 1906.

KAPSA, Václav. Hudebnici hraběte Morzina: príspěvek $k$ dějinám šlechtických kapel v Čechách $v$ době baroka: s tematickými katalogy instrumentálni tvorby Antonína Reichenauera, Christiana Gottlieba Postela a Františka Jiránka. Etnologický ústav Akademie věd České republiky, Kabinet hudební historie, Praha, 2010.

MAŇAS, Vladimír. K osudům moravského barokního kazatele Antonína Ferdinanda Dubravia. In Opus Musicum, č. 1, Brno, 2010, s. 31-41.

PEČMAN, Rudolf (ed.). Vladimír Helfert v českém a evropském kontextu. Svaz čes. skladatelů a koncertních umělců, Brno, 1987.

PEČMAN, Rudolf. Vladimír Helfert. Nadace Universitas Masarykiana, Brno, 2003.

PEČMAN, Rudolf. Preambulum aneb Brněnská muzikologie v době počátku a prvních vzmachů. In Musicologia Brunensis. Ad honorem Jan Racek, Bohumír Štědroň et Zdeněk Blažek 1905 2005. Koniasch Latin Press, Praha, 2005, s. 7-32.

PERUTKOVÁ, Jana. Zur Identifizierung der Questenbergischen Partituren in Wiener Musikarchiven. In Hudební věda, č. 1, 2007, s. 5-34

PERUTKOVÁ, Jana. František Antonín Míča ve službách hraběte Questenberga a italská opera v Jaroméricich. Koniasch Latin Press, Praha, 2011.

PERUTKOVÁ, Jana. Moravská hudbymilovná aristokracie v 1. polovině 18. století a její vztah ke světským hudebně dramatickým produkcím. In Opus Musicum, roč. 45, č. 3, Brno, 2013, s. 6-12.

PERUTKOVÁ, Jana. Neu identifizierte Opernpartituren aus der Musiksammlung des Grafen Johann Adam von Questenberg. In MACEK, Petr - PERUTKOVÁ, Jana (ed.). The Eighteenth - Century Italian Opera Seria: Metamorphoses of the Opera in the Imperial Age, International Musicological Colloquium. Praha, 2013, s. 55-70.

PILKOVÁ, Zdeňka. Česká hudba 18. století v díle Vladimíra Helferta. Konfrontace s dnešním stavem výzkumu. In PEČMAN, Rudolf (ed.). Vladimír Helfert v českém a evropském kontextu. Svaz čes. skladatelů a koncertních umělců, Brno, 1987, s. 60-63.

PLICHTA, Alois (ed.). O životě a umění. Listy z jaroměřické kroniky 1700-1752. Jaroměřice nad Rokytnou, 1974.

PLICHTA, Alois. Jaroměřicko. Dějiny Jaroměřic nad Rokytnou a okolí. I-II, Třebíč, 1994.

SEHNAL, Jiří. Počátky opery na Moravě. In O divadle na Moravě. Acta Universitatis Palackianae Olomucensis, Facultas Philisophica Supplementum 21, Praha, 1974, s. 55-77.

SEHNAL, Jiří. Vladimír Helfert a baroko. In PEČMAN, Rudolf (ed.). Vladimír Helfert v českém a evropském kontextu. Svaz čes. skladatelů a koncertních umělců, Brno, 1987, s. 43-45.

SMÍŠEK, Rostislav. Jan Adam z Questenberka a hmotná kultura v zámku v Jaroměřicích nad Rokytnou. Př́spěvek ke šlechtické reprezentaci v první polovině 18. století. In Západní Morava. Muzejní a vlastivědná společnost v Brně, roč. 9, Brno, 2005, s. 50-70.

SPÁČILOVÁ, Jana. Hudba na dvoře olomouckého biskupa Schrattenbacha (1711-1738). Př́spěvek k libretistice barokní opery a oratoria. Disertační práce, FF MU, Brno, 2006.

STRAKOVÁ, Theodora. Jaroměřice nad Rokytnou. In Opus Musicum 4, 1973, č. 2, s. 57-60.

STRAKOVÁ, Theodora. Jaroměřice nad Rokytnou a jejich význam v hudebním vývoji Moravy. In PLICHTA, Alois (ed.). O životě a umění. Listy z jaroměřické kroniky 1700-1752. Jaroměřice nad Rokytnou 1974, s. 393-404.

STRAKOVÁ, Theodora. Vladimír Helfert a zámecká hudební kultura. In PEČMAN, Rudolf (ed.). Vladimir Helfert v českém a evropském kontextu. Svaz čes. skladatelů a koncertních umělců, Brno, 1987.

STRAKOVÁ, Theodora. Die Questenbergische Musikkapelle und ihre Repertoire. In Sborník praci Filozofické fakulty brněnské univerzity, H 31, 1996 [Brno 1997], s. 13-23.

ŠŤĚDROŇ, Bohumír. Dr. Vladimír Helfert: prehled práce českého učence. Knihovna unie českých hudebníků z povolání, č. 30, Praha, 1940. 
VOLEK, Tomislav. 90 Jahre seit dem Erscheinen der Studie von Vladimír Helfert über Don-Juan-Oper in Brünn 1734. In MACEK, Petr - PERUTKOVÁ, Jana (ed.). The Eighteenth - Century Italian Opera Seria: Metamorphoses of the Opera in the Imperial Age, International Musicological Colloquium. Colloquia Musicologica Brunensia, 42, Koniasch Latin Press, Praha, 2013, s. $115-125$.

VOLEK, Tomislav. Helfert stále aktuální. In Opus Musicum, č. 10, 1986, s. 306-310. 